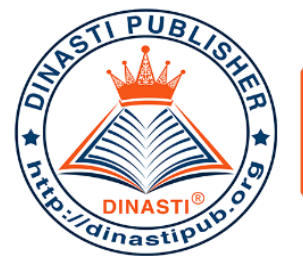

\title{
ANALYSIS OF CUSTOMER LOYALTY THROUGH THE FAST RESTAURANT CUSTOMER SATISFACTION FACTOR
}

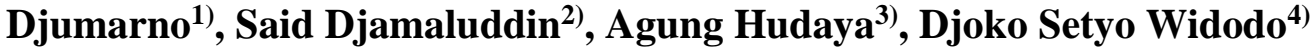 \\ 1) Lecturer, Universitas Mercu Buana (UMB), Jakarta Indonesia \\ 2) Lecturer, Universitas Mercu Buana (UMB), Jakarta Indonesia \\ 3) Lecturer, Universitas Mercu Buana (UMB), Jakarta Indonesia \\ 4) Lecturer, Universitas Gunadarma, Jakarta Indonesia
}

\begin{tabular}{|c|c|}
\hline $\begin{array}{l}\text { ARTICLE INFORMATION } \\
\text { Received: } 12 \text { August } 2020 \\
\text { Revised: 25 September } 2020 \\
\text { Issued: } 9 \text { November } 2020 \\
\text { Corresponding author: Djurmarno } \\
\text { E-mail: } \\
\text { sjumarno@mercubuana.ac.idd } \\
\text { said_djamaluddin@mercubuana.ac.id } \\
\text { agung24@mercubuana.ac.id }^{3)}\end{array}$ & $\begin{array}{l}\text { Abstract: Economic growth and the growth of } \\
\text { restaurant activities is very rapid, will affect many } \\
\text { aspects of the economy, the need for staples, and } \\
\text { other needs make distribution of merchandise will be } \\
\text { increasingly busy. Business people will create } \\
\text { strategies to complement the needs of the } \\
\text { community or consumers. Nowadays, restaurant } \\
\text { business is a solution for entrepreneurs, because the } \\
\text { busyness of the community will make them prefer } \\
\text { the meaning of fast food. Consumers will see the } \\
\text { quality of products from the retail store they will } \\
\text { buy, as well as the quality of service, whether the } \\
\text { brand image displayed by fast food restaurants is in } \\
\text { accordance with customer satisfaction. It is expected } \\
\text { that loyalty will arise if satisfaction arises in the } \\
\text { minds of these consumers. Data analysis techniques } \\
\text { used are correlation analysis techniques and SEM } \\
\text { (structural equation model) analysis techniques. } \\
\text { Correlation analysis techniques to determine the } \\
\text { relationship between variables, while SEM analysis } \\
\text { techniques to determine how much influence the } \\
\text { independent variable has on the dependent variable. } \\
\text { The software used to process and analyze data from } \\
\text { this study is Smart PLS version } 3.0 \text {. } \\
\text { Keywords: service quality, brand image, customer } \\
\text { satisfaction, customer loyalty, restaurants, fast food. }\end{array}$ \\
\hline
\end{tabular}

\section{INTRODUCTION}

Today, we often meet with the growth of the culinary business industry in the form of food in Indonesia, This has resulted in more and more variables that can affect the success of a business. Companies must strive to learn and understand the needs and desires of their 
customers. By understanding the needs, desires and demands of customers, it will provide important input for companies to design marketing strategies so as to create satisfaction for consumers.

Fast food or Fast Food has been known by the public as an alternative food that can be filling and can be consumed quickly and buy it very quickly to get it and easily. Fast food alone means fast food where consumers do not have to wait or need a long time to eat fast food because peacock messages can be consumed immediately because the process is very easy and fast.

This concept is indispensable for today because millennial times such as those today that are all practical and the time needed to manage the meal must also be very quickly consumed and from that satisfaction or consumer dissatisfaction is part of the consumer experience of a product or services offered. Based on the experience gained, consumers have a tendency to build certain values.

This value will provide an impact for consumers to make comparisons of competitors from products or services they have ever felt. Consumer expectations are an important factor, services that are closer to consumer satisfaction will provide more hope and vice versa. Product quality has functions which include durability, reliability, accuracy of ease of operation and repair, as well as other valuable attributes. To improve product quality the company can implement various programs that support KFC products so that it can be sought after by consumers.

The most important characteristic for most restaurant businesses is the brand or brand in a food and what the brand presents. To beat competitors in the fast food field and always be a market leader, you must maintain your brand and have strong brand equity. This research was conducted at a Kentucky Fried Chicken fast food restaurant in Indonesia. This study analyzes customer-based brand equity in the company.

The development of the restaurant business is also related to consumer behavior that likes to eat outside the home, be it alone, with friends or family. According to the online newspaper article "Merdeka" which discusses a survey conducted by Ipsos Indonesia, 90 of the third largest independent market research companies that were first established in France, Indonesians are not too fond of cooking.

Respondents who enjoy enjoying their own culinary are only 34 percent, another 15 percent like the cuisine of famous chefs. However, the highest number is 51 percent of respondents who like to buy food in foreign restaurants, for example American-style fried chicken or Japanese and Korean food, (Mohamad 2013).

\section{Table 1.1 FAST FOOD RESTAURANT SURVEY IN INDONESIA'S TOP BRANDS OF 400 PERSONS}

\begin{tabular}{lll}
\hline N & Restaurant Name & Repondens \\
O. & & \\
\hline 1 & KFC & $56 \%$ \\
2 & McDonald's & $27 \%$ \\
3 & Hoka-Hoka Bento & $5,80 \%$ \\
4 & Pizza Hut & $4,80 \%$
\end{tabular}




\begin{tabular}{lll}
5 & $\begin{array}{l}\text { Restoran Cepat Saji } \\
\text { Yang Lain }\end{array}$ & $7,00 \%$ \\
\hline Total & & $\mathbf{1 0 0 \%}$ \\
\hline
\end{tabular}

Source : (Andreani et al, 2012)

In several surveys, KFC has always ranked first in the Indonesian top of mind. W\&S Market Research conducted a simultaneous survey of the popularity of fast food restaurants in three countries: Indonesia, Vietnam, and Thailand. 400 Indonesian respondents were asked questions to name known fast food restaurants, 55.5 percent mentioned KFC, 27 percent mentioned McDonald's "s, 5.8 percent mentioned Hoka-Hoka Bento, 4.8 percent mentioned Pizza Hut, and the rest were other fast food restaurants. ("KFC is more popular than Pizza Hut", 2016, September).

Phenomenon or competitors from journals that have been discussed or reviewed above are many competitors faced by KFC, but in the survey or research site, which is located around KFC Alam Sutera Tangerang, 5 kilometers away, such as Pizza Hut, McDonald's, Domino Pizza, HokBen, Akpoyomare (2012), Abdillah (2012), Rousset (2017) Saleem (2012) Mustafa. (2012)

\section{Identification of problems}

1. Does service quality affect customer satisfaction at KFC Alam Sutera?

2. Does brand image influence customer satisfaction at KFC Alam Sutera?

3. Does customer satisfaction affect customer loyalty at KFC Alam Sutera?

In accordance with the problems posed in the study, the objectives of this research are: Based on the use of the research formula, the objectives of the study are as follows:

1) To analyze the effect of service quality on customer satisfaction.

2) To analyze the effect of brand image on store customer satisfaction.

3) To analyze customer satisfaction with store customer loyalty.

\section{LITERATURE REVIEW}

\section{Service Quality}

Service quality encourages customers to commit to a company's products and services so that it has an impact to increasing the market share of a product.

According to Tjiptono (2012). Quality of service is something that is perceived by the customer. Customers will judge the quality of a service that is felt based on what they describe in their minds. Customers will turn to other service providers who are better able to understand the specific needs of customers and provide better services.

\section{Brand Image}

Caniago, Suharyono, Arifin, dan Kumadji (2014) stated that service quality significantly affects the brand image and re-branding of the company.

In an organization, an image can be formed from two factors, namely internal factors and external factors. To that end, organizations have the ability to direct the image desired by consumers : 


\section{Mirror}

The leader has a very important role in shaping the image. Mirror image can survive during the leadership period, the figure is considered good by the community. If there is a change of leadership the image of the organization can change even if the changes do not occur drastically.

\section{Current}

Current image is an image formed by the community that is not included in the internal organization. This can affect the image in general, for example if an organization makes a mistake and the public knows it will automatically produce an image that is not good even though in reality the organization has done things that can support the formation of a good image, but is not known by the public.

Wish

Wish image is formed in accordance with the ideals or expectations of the organization and is usually stated in the vision and mission of the organization. This image is not appropriate if it only depends on expectations and is not followed by action or real effort to make it happen.

\section{Corporate}

Corporate image looks more at organizations than products or services that have been produced. For organizations that are already strong, they generally have a corporate image that has been built a long time ago and has a good reputation. If an organization has all of these, then the thing to do next is to maintain or maintain the position through the services and products or services produced.

\section{Multiple}

Multiple images is an image created by various elements in the organization. In this case, symbols, attributes and logos can represent the formation of the image of an organization.

A positive consumer image of a brand makes it possible for consumers to make a purchase. A better brand is also the basis for building a positive corporate image so that it can be said that brand image is an asset of the company because it has an impact on consumer perception.

According to Gronroos, quoted by Fandy Tjiptono (2011) has identified four roles of image, namely:

1. The image reflects the hopes, ideals along with external marketing campaigns through advertising, personal sales and word of mouth communication. A positive image makes it easier for organizations to communicate.

2. Image as a filter that affects the perception of an organization's activities. The technical and functional qualities are seen through this filter. If the image is good, the image becomes protective.

3. Image is a function of consumer experience and expectations. When consumers want the expectations and reality of experience in the form of perceived technical and functional service quality resulting in a change in image, if the service meets and exceeds expectations, the image gets strengthened and even increases.

4. Image has an important influence on management and internal organization. The image is not good and not clear will have an effect on employee attitudes towards the organization.

Janonis and Virvilaite (2007) stated in the marketing literature, brand image can be studied through two approaches namely from the approach of companies and consumers. 
The approach of consumers based on conditions in the market can be seen from the company's ability to evaluate the reality of how consumers interpret the brand image and the company's ability to set strategies in brand positioning and reveal brand equity to consumers.

\section{Cutomer Satisfaction}

Kotler \& Keller (2016) states satisfaction is a feeling of pleasure or disappointment someone appears after comparing the perceptions / questions about the performance or results of a product and its expectations. Satisfaction is a function of perception / impression of performance and expectations. If performance meets expectations, customers are dissatisfied. If the performance is below expectations, the customer is satisfied. If performance exceeds expectations, the customer is very satisfied and happy, so customer satisfaction requires a balance between the needs and wants (need and want) with what is given (given).

\section{Customer Loyalty}

According to Griffin (2014) the definition of loyalty as a form of behavior of decisionmaking units to make purchases continually on the goods / services of a selected company. defines loyalty as a customer's commitment to deeply re-subscribe or re-purchase selected products / services consistently in the future. Although the influence of the situation and marketing efforts have the potential to cause behavior change.

Framework

The influence of service quality on customer satisfaction

Based on research by Malik, et al (2012) Services provided to customers can affect customer satisfaction. If the services provided can meet customer expectations, customers will feel happy and will increase interest in visiting.

The influence of brand image on customer satisfaction

Based on the research of Yu-Te Tu et. al (2012) and Malik, et al (2012) brand image influences customer satisfaction. The image of a brand becomes a basis for customers to be able to recognize a product to be purchased and gain experience from a product, brand image has the opportunity to achieve customer satisfaction.

The effect of customer satisfaction on customer loyalty

Based on research conducted by Abdillah (2017), when customer satisfaction increases, customer loyalty will also increase, and vice versa decreasing customer satisfaction will make customer loyalty also decreases.

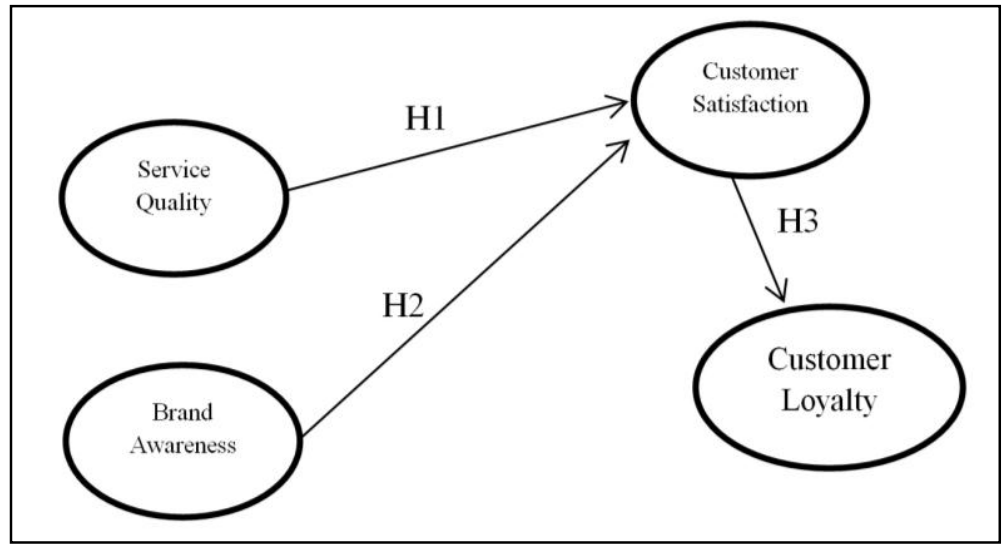

Figure 1 Framework 


\section{Hypothesis}

Based on the problem examined, then a hypothesis is drawn as follows:

H1: Service Quality affects Customer Satisfaction

$\mathrm{H} 2$ : Brand Awareness affects customer satisfaction

H3: Customer Satisfaction influences customer loyalty

\section{RESEARCH METHODS}

In this study the variables measured using the instrument in the form of a questionnaire using a form that meets statement Likert type scale and distributed to the consumer in Coffee Shop Gerobak kopi Jakarta.

model in this study is a model of causality (cause and effect relationship or the influence), then to test the hypothesis used test equipment Structural Equation Model (Structural Equation Modeling - SEM), using PLS 3.0 program. Cutomer Loyalty and Customer Satisfaction as dependent variables, Service Quality and Brand Image as the dependent variable.

The method can be illustrated as shown in Figure 1 above with the structure and sub structure of the path as below:

$$
\begin{aligned}
& Z=\text { Pyx } 1 . X 1+\text { Pyx } 2 . X 2+\varepsilon 1 \\
& Y=\text { Pzy.Z }+\varepsilon
\end{aligned}
$$

Note: $\mathrm{X} 1=$ Service quality; $\mathrm{X} 2=$ Brand Image $; \mathrm{Z}=$ Customer satisfaction; $\mathrm{Y}=$ Customer Loyalty; and $\mathcal{E}=$ epsilon (other factors that influence)

\section{FINDINGS AND DISCUSSION}

\section{Research result}

There are three values that must be considered at this stage, namely convergent validity, discriminant validity, and composite reliability.Convergent validity, the correlation between the reflexive indicator scores and the latent variable scores. This research uses loading 0.5 to 0.6 is considered sufficient, because it is the initial stage of developing the measurement scale

and the number of indicators per construct is not large, namely 2 (two) to 4 (four) indicators.Discriminant validity, reflexive indicator measurement based on cross loading with its latent variables. Another method is by comparing the square root of average variance extracted (AVE) values of each construct with the correlation between other constructs in the model. If the initial measurement values of the two methods are better than the other construct values in the model, it can be concluded that the construct has a good discriminant validity value or vice versa. Accordingly, it is recommended that the measurement value be greater than 0.50.Composite reliability, a block indicator that measures the internal consistency of construct indicators, shows the degree to which it indicates common latent (unobserved). The construct is declared reliable if it has a composite reliability value above 0.70 and Cronbach's alpha above 0.60 even though it is not an absolute standard.

\section{Convergent Validity}

Convergent validity is used to determine instrument items that can be used as indicators of overall latent variables. The results of this test are measured based on the value of the loading factor (external loading) of the construction indicator. The following convergent validity test results are presented in the table 
Table 1. Table of Convergent Validity Test Results .

\begin{tabular}{llll}
\hline Variable & Indicator & Outer Loadings & Result \\
\hline Service quality & X1.1 & 0.777 & Valid \\
& X1.2 & 0.813 & Valid \\
& X1.3 & 0.755 & Valid \\
X1.4 & 0.793 & Valid \\
\hline Brand Image & X2.1 & 0.855 & Valid \\
& X2.2 & 0.824 & Valid \\
& X2.3 & 0.920 & Valid \\
& X2.4 & 0.784 & Valid \\
& X2.5 & 0.756 & Valid \\
\hline Customer satisfaction & Z1.1 & 0.718 & Valid \\
& Z1.2 & 0.819 & Valid \\
& Z1.3 & 0.891 & Valid \\
& Z1.4 & 0.778 & Valid \\
& Z1.5 & 0.793 & Valid \\
& Z1.6 & 0.798 & Valid \\
\hline Customer loyalty & Y1.1 & 0.855 & Valid \\
& Y1.2 & 0.750 & Valid \\
& Y1.3 & 0.835 & Valid \\
\hline
\end{tabular}

Source: Data processed from Smart PLS output

The table shows that all outer loading factors have values greater than 0.5 . So that this measurement can be concluded has met the requirements of convergent validity. The convergent validity of the measurement model using reflective indicators is assessed based on the outer loading factor of the indicators that measure the construct. In this study there are 5 constructs with a number of indicators ranging from 3 to 10 indicators with a scale of 1 to 5. If the correlation coefficient is equal to 0.3 or more (at least 0.3 ) then the instrument is declared valid, and invalid if the correlation coefficient is smaller than 0.3 (Sugiyono, 2006) states based on the results of the loading factors above, it is concluded that the construct which has a dominant loading factor above 0.5 has a good convergent validity.

Validity test is also performed by testing the method of comparing the value of the square root of average variance extracted (AVE) in each construct with the correlation between other constructs contained in the model.

Table 2. Testing Results Table AVE

VARIABEL

Service quality

Brand Image

Customer satisfaction

Customer loyalty

\section{Average Variance}

Extracted (AVE)

0.616

0.688

0.642

0.717

Source: Data processed from Smart PLS output

\section{Composite Reliability and Cron bach's Alpha}

In addition to the construct validity test, the construct reliability test is also measured by the composite reliability and Cronbach's alpha of the indicator block that measures the 
construct. Following are the results of reliability testing and Cronbach alpha composites from Smart PLS:

Table 3. Composite Reliability and Cron bach's Alpha tables

\begin{tabular}{lll} 
Variabel & Cronbach's Alpha & $\begin{array}{l}\text { Composite } \\
\text { Reliability }\end{array}$ \\
\hline Service quality & 0.793 & 0.865 \\
Brand Image & 0.885 & 0.917 \\
Customer satisfaction & 0.888 & 0.915 \\
Customer loyalty & 0.803 & 0.884 \\
\hline
\end{tabular}

Source: Data processed from Smart PLS output

This construct is stated to be reliable if it has a composite reliability value above 0.70 and Cronbach's alpha above 0.60. From the Smart PLS output above all construction has a composite reliability value above 0.70 .

The measurement model for the validity and reliability test, the coefficient of determination of the model and the path coefficient for the equation model, can be seen in the following figure:

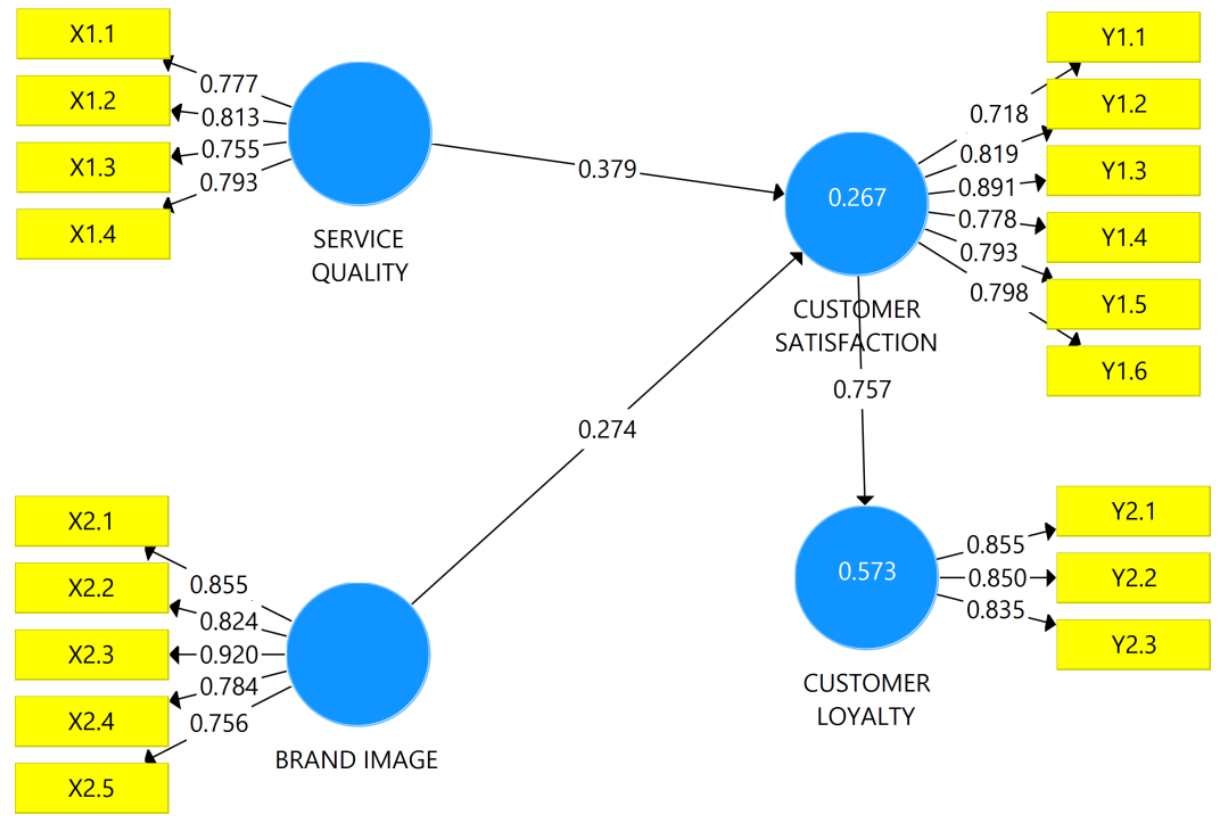

Figure 2. PLS Algorithm

Source: Data processed from Smart PLS output

\section{Structural Model Testing (Inner Model)}

The structural model in PLS is evaluated using R2 for the dependent variable and the path coefficient for the independent variables then the significance is assessed based on the tstatistic value of each path. The structural model of this research can be seen in the following figure: 


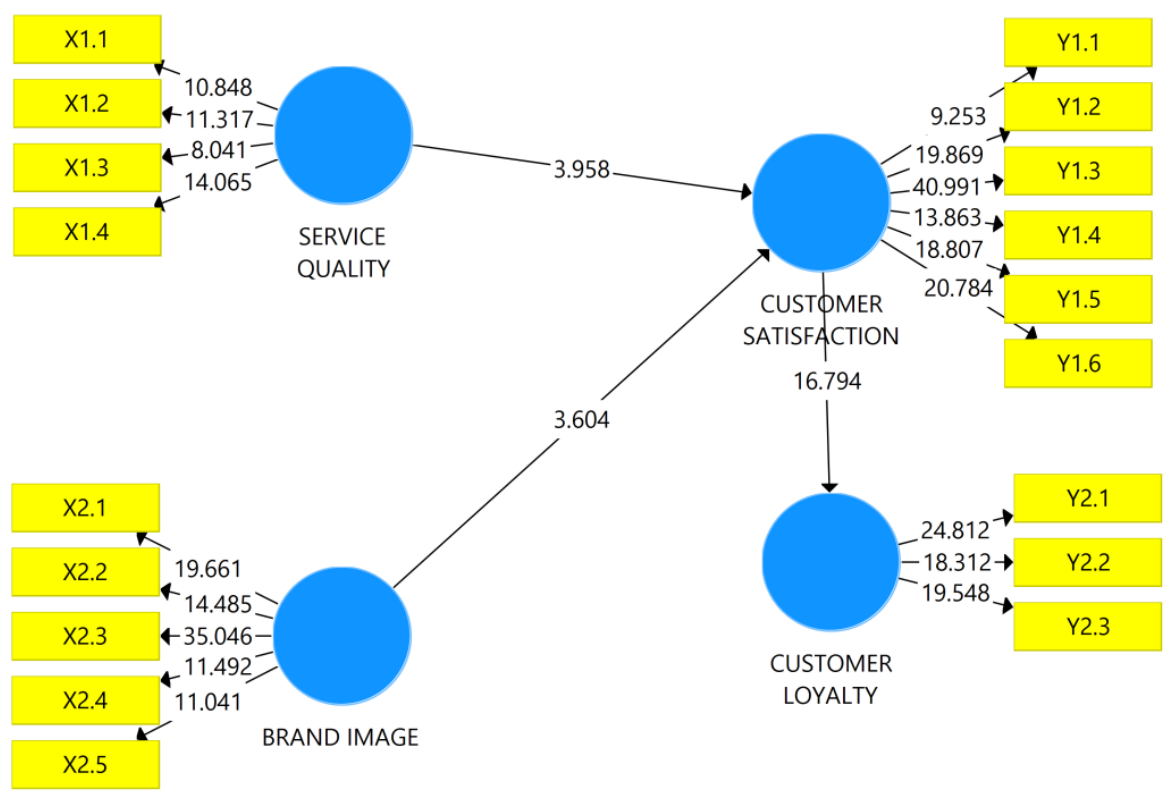

Figure 3. Display of PLS Bootstrapping Results

Source: Data processed from Smart PLS output

R2 values for each endogenous variable in this study can be seen in Table :

Table 4. $R$-Square table

\begin{tabular}{lll}
\hline Variable & $\boldsymbol{R}$ Square & R Square Adjusted \\
\hline Customer satisfaction $(\mathrm{Z})$ & 0.267 & 0.252 \\
Customer loyalty (Y) & 0.573 & 0.569 \\
\hline
\end{tabular}

Source: Data processed from Smart PLS output

R Square Value of Customer satisfaction $(\mathrm{Z})$ of 0.267 shows a double correlation (service quality and brand image). And R Square Customer loyalty Value (Y) of 0.573 shows a double correlation (service quality, Brand image and customer satisfaction)

\section{Goodness of Fit}

In the next stage the model evaluation will be carried out through goodness of fit. Goodness of fit assessment is known from the Q-Square value. Q-Square value has the same meaning as the coefficient of determination (R-Square) in the regression analysis, where the higher the Q-Square, the model can be said to be more suitable with the data. The results of calculating the Q-Square values are as follows:

Q-Square $=1-[(1-0,267) \times(1-0,573)]$

$=1-(0,733 \times 0,754)$

$=1-0,552$

$=0,448$

Based on the calculation above, the Q-Square value of 0.448 is obtained. This shows the amount of diversity of research data that can be explained by the research model is $44.8 \%$, Based on these results, the model in this study can be stated to have had an excellent goodness of fit. 
Table 5. Path Coefficients table (Mean, STDEV, t-Value)

\begin{tabular}{lllll}
\hline Variable & $\begin{array}{l}\text { Original } \\
\text { Sample }\end{array}$ & T Statistics & P Values & nificance Level \\
Service quality -> Customer satisfaction & 0.379 & 3.795 & 0.000 & $<0.05$ \\
Brand Image -> Customer satisfaction & 0.274 & 3.572 & 0.000 & $<0.05$ \\
Customer satisfaction -> Customer loyalty & 0.757 & 18.828 & 0.000 & $<0.05$ \\
\hline
\end{tabular}

Based on the table above it can be seen that the measurement model formed is the Equation Model as below:

$\mathrm{Z}=\mathbf{0 . 3 7 9 X 1}+\mathbf{0 . 2 7 4 X 2}$

$\mathrm{Y}=\mathbf{0 . 7 5 7 Z}$

Dimana,

$\mathrm{X} 1=$ Service quality

$\mathrm{X} 2=$ Brand Image

$\mathrm{Z}=$ Customer satisfaction $\mathrm{Y}=$ Customer loyalty

The equation above can be interpreted as follows:

1. Service quality Variables have a positive coefficient direction on Customer satisfaction

2. Brand equity Variables have a positive coefficient direction on Customer satisfaction

3. The Customer satisfaction Variable has a positive direction coefficient on Customer loyalty

\section{Hypothesis testing}

1) The Influence of service quality on customer satisfaction

The first hypothesis which states that service quality Influences customer satisfaction can be proven true. This can be seen from the statistical t value of 3.795 which is greater than the value of $t$ table $=1.96$, and a probability value of 0,000 which is smaller than the specified critical value limit of 0.05 . Thus it is stated that product quality has significant and significant effect on customer satisfaction.

The difference related to the relationship between service quality and customer satisfaction could be due to differences or distinctiveness of the object of study under study. Where the level of service quality of the object under study or in other words the object under study is not a product / object that is known by the public is likely to be one of the causes. In Ali, H (2016) Model of customer satisfaction, Yunita, D., Ali, H. (2017) Model of Purchasing Decision (Renting) of Generator Set: Analysis of Product Quality, Price an Service at PT. Hartekprima Listrindo. Limakrisna, N., Ali, H. (2016). Model of customer satisfaction: Empirical study at fast food restaurants in bandung. Agussalim, M., Ali,H. (2017)

\section{2) The Influence of brand image on customer satisfaction}

The second hypothesis which states that brand image Influences customer satisfaction can be proven true. This can be seen from the statistical $t$ value of 3.572 which is greater than the value of $t$ table $=1.96$, and the probability value of 0.006 which is smaller than the specified 
critical value limit of 0.05 . Thus it is stated that price perception has significant and significant influence on customer satisfaction.

There is a correlation in this research between brand image variables on customer satisfaction which states that increasing will have an impact on customer satisfaction that are also high in accordance with research Sulistiorini, MS., Ali, H. (2017). Customer Satisfaction Model: Product Analysis, Price, Promotion and Distribution (Case Study At Pt Integrasia Utama). Konuk, F. A. (2019). The influence of perceived food quality, price fairness, perceived value and satisfaction on customers' revisit and word-of-mouth intentions towards organic food restaurants El-Adly, M. I. (2019)Ikhsani, K., Ali, H.(2017).

\section{3) The Influence of customer satisfaction on customer loyalty}

The hypothesis which states that the customer satisfaction influences the customer loyalty can be proven true. This can be seen from the statistical $t$ value of 18.828 which is greater than the value of $t$ table $=1.96$, and the probability value of 0.000 which is smaller than the specified critical value limit of 0.05 . Thus it is stated that the customer satisfaction has significant influence on the customer loyalty.

Variable purchase intention with a purchase decision has a strong enough relationship value. Xie, Y. (2020). The relationship among marketing mix, customer satisfaction and customer loyalty of Chinese tourists to budget hotel of central Bangkok. El-Adly, M. I. (2019). Modelling the relationship between hotel perceived value, customer satisfaction, and customer loyalty. Turuis, T. F. (2019). Cheng, B. L., Gan, C. C., Imrie, B. C., \& Mansori, S. (2019). Service recovery, customer satisfaction and customer loyalty. Ely, R. (2019). The effect of product quality to the customer satisfaction and customer loyalty on the local food.

\section{CONCLUSION AND SUGGESTION}

Based on the discussion in the previous chapter, the results of this study can be concluded as follows:

1. In this research it can be seen that service quality influences customer satisfaction, because the data shows the direction of the positive and significant coefficient on customer satisfaction. Therefore customer satisfaction is closely related to service quality, with good service quality will have a good impact Back to customer satisfaction, an indicator of service quality greatly affects customer satisfaction. Moreover, in the case of fast food restaurants, related to food, consumers will be more selective in choosing because it is related to what they will consume. The characteristics formed by service quality are characteristics that will benefit the restaurant, because it will have an impact on consumers who have a sense of customer satisfaction

2. Brand image has a positive and significant effect on customer satisfaction, this shows that the relationship is strong enough between brand image to customer satisfaction, with the presence of brand equity from a good restaurant in the form of a brand that is always remembered by customers, a good brand is a strong brand, building a brand is not as easy as making a product, it takes energy and time to build a brand, with this, to get good brand equity, you must have good brand equity.

3. Customer Satisfaction has a positive and significant influence on customer loyalty. Loyalty can be said to be the final level of customer satisfaction, because with a loyal customer will create a good relationship, between restaurants and customers, customers can tell good things from the company to others, customers can also repurchase products continuously to the restaurant if they already loyal to the restaurant. This will be formed because of customer satisfaction, therefore the restaurant must wisely form customer 
satisfaction first, with a series of customer satisfaction that has been created by the restaurant, it will be easier to bring out customer loyalty to customers.

\section{Suggestion}

The restaurant must wisely establish service quality by paying attention to shop assistants, both in terms of dressing, greeting customers, and behaving. Service can also be seen in terms of, products from restaurants, the restaurant must pay attention to the packaging of each product for their sale, packaging is very influential on customer satisfaction, because packaging is also competing competitively for the time being. A good store brand will be easier for the restaurant in maintaining customer satisfaction and customer loyalty, because a good brand is not easy to achieve. The restaurant must maintain the brand in a more careful way, with a brand that is already good in the eyes of the customer, the restaurant it will be easier to get customer satisfaction and customer loyalty. Customer loyalty that has been formed with service quality and brand image, and customer satisfaction. Customer loyalty can be said to be the goal of the company, because if the customer is loyal to a product or restaurant, then it does not mean that they will come back again to buy products and visit restaurants, customer loyalty will result in a positive psychology to a perspective on what the customer like it. This will lead to repeat purchases.

\section{REFERENCE}

Agussalim, M., Ali,H. (2017). Model Kepuasan Pelanggan: Analisis Kualitas Produk Dan Kualitas Layanan Terhadap Citra Merek Pada Giant Citra Raya Jakarta. Jurnal Manajemen 21 (3), 317-335.

Alafityanto, A., \& Djumarno, D. (2018) Pengaruh Kualitas Produk, Harga Produk dan Distribusi terhadap Kepuasan Pelanggan Serta Pengaruhnya terhadap Loyalitas Customer (Study pada PT Berri Indosari). Swot, 7(2).

Ali, H., Hadibrata,B., Buchori, CD. (2016). One Stop Services: Quality of Service and Accessibility to

Ali, H., Limakrisna, N., \& Djamalluddin, S. (2016). Model of customer satisfaction: the empirical study at BRI in Jambi. International Journal of Applied Business and Economic Research, 707-719.

Bergel, M., \& Brock, C. (2019). Visitors' loyalty and price perceptions: the role of customer engagement. The Service Industries Journal, 39(7-8), 575-589

Cheng, B. L., Gan, C. C., Imrie, B. C., \& Mansori, S. (2019). Service recovery, customer satisfaction and customer loyalty: evidence from Malaysia's hotel industry. International Journal of Quality and Service Sciences.

Djumarno, S. A., \& Djamaluddin, S. (2018). Effect of Product Quality and Price on Customer Loyalty through Customer Satisfaction. International Journal of Business and Management Invention (IJBMI), 7(8), 12-20.

Djumarno, S. A., \& Djamaluddin, S. (2018). Effect of Product Quality and Price on Customer Loyalty through Customer Satisfaction. International Journal of Business and Management Invention (IJBMI), 7(8), 12-20. 
Djumarno, S. O., \& Djamaludin, S.(2017): The Effect of Brand Image, Product Quality, and Relationship Marketing on Customer Satisfaction and Loyalty. Journal of Business Marketing and Management, 15-24.

El-Adly, M. I. (2019). Modelling the relationship between hotel perceived value, customer satisfaction, and customer loyalty. Journal of Retailing and Consumer Services, 50, 322-332.

Ely, R. (2019). THE EFFECT OF PRODUCT QUALITY TO THE CUSTOMER SATISFACTION AND CUSTOMER LOYALTY ON THE LOCAL FOOD (Case Study in PT

ASESE) (Doctoral dissertation, Universitas Andalas).

Ghozali, Imam. (2011). Aplikasi Analisis Multivariate Dengan Program SPSS. Semarang, Edisi 5. BP

Griffin, Ricky W., and Moorhead, Gregory., 2014. Organizational Behavior: Managing People and Organizations. Eleventh Edition. USA: South Western

HUDAYA, A. (2018). ANALISIS FAKTOR YANG MEMPENGARUHI KEPUTUSAN

PEMBELIAN (Studi kasus kedai Gerobak Kopi Seruput Jakarta) (Doctoral dissertation, Universitas Mercu Buana Jakarta).

Hui-Chun Huang Ya-Ting Chang Che-Yi Yeh Chung-Wei Liao , 2014, Promote the price promotion. International Journal of Contemporary Hospitality Management, . 26 (7) 1065 1082

Ikhsani, K., Ali, H. (2017). Keputusan Pembelian: Analisis Kualitas Produk, Harga dan Brand Awareness (Studi Kasus Produk Teh Botol Sosro di Giant Mall Permata Tangerang). Swot 7 (3), 523-541

Konuk, F. A. (2019). The influence of perceived food quality, price fairness, perceived value and satisfaction on customers' revisit and word-of-mouth intentions towards organic food restaurants. Journal of Retailing and Consumer Services, 50, 103-110.

Kotler, Philip . (2012). Prinsip-prinsip Pemasaran .Edisi Ketigabelas Jilid I. Erlangga. Jakarta.

Kotler, Philips \& Amstrong, Gary (2012). Prinsip-prinsip Pemasaran Edisi 13, Jilid 1, Jakarta : Erlangga.

Kottler, Philip, Keller, L Kevin (2012). Manajemen Pemasaran. Edisi 12. Jakarta: Erlangga.

Limakrisna, N., Ali, H. (2016). Model of customer satisfaction: Empirical study at fast food restaurants in bandung. International Journal Of Business And Commerce 5 (6), 132- 146.

Nafisa, J., \& Sukresna, I. M. (2018). Analisis Pengaruh Kualitas Layanan, Harapan Kinerja Dan Citra Perusahaan Terhadap Loyalitas Pelanggan Melalui Kepuasan Pelanggan Sebagai Variabel Intervening (Studi Pada Rumah Sakit Islam Sultan Agung Semarang). Diponegoro Journal Of Management, 7(4), 78-104.

Nwachukwu, A., Benson-Eluwa, V., Valentine, I. E., \& Keneth, O. (2019). Product Quality Perception and Customer Loyalty. Archives of Business Research, 7(3.2). 
Rohwiyati, R., \& Praptiestrini, P. (2019). The Effect of Shopee e-Service Quality and Price Perception on Repurchase Intention: Customer Satisfaction as Mediation Variable. Indonesian Journal of Contemporary Management Research, 1(1), 47-54.

Romdonny, J., \& Rosmadi, M. L. N. (2019). Factors Affecting Customer Loyalty in Products. Budapest International Research and Critics Institute (BIRCI-Journal): Humanities and Social Sciences, 2(1).

SiVARAM, M., Hudaya, A., \& Ali, H. (2019). BUILDING A PURCHASE AND PURCHASE DECISION: ANALYSIS OF BRAND AWARENESS AND BRAND

LOYALTY. Dinasti International Journal of Education Management And Social Science, 1(2), 235-248.

Sugiyono. (2009). Metode Penelitian Bisnis. Alfabeta. Bandung.

Sugiyono. (2011). Metode Penelitian Pendidikan (Pendekatan Kuantitatif, Kualitatif dan $R \& D)$. Alfabeta. Bandung.

Sulistiorini, MS., Ali, H. (2017). Customer Satisfaction Model: Product Analysis, Price, Promotion and Distribution (Case Study At Pt Integrasia Utama). International Journal of Applied Business and Economic Research. the Investor Loyalty: The Investment Coordinating Board. International Journal of Business and Commerce.

Te Tu, Y., Wang, C. M., \& Chang, H. C. (2012). Corporate Brand Image and Customer Satisfaction on Loyalty: An Empirical Study of Starbucks Coffee in Taiwan. Taiwan. Journal of Social and Development Sciences, 3(1), 24-32.

Tjiptono, Fandy \& Gregorius Chandra (2011). Service, Quality \& Satisfaction. Edisi 3, Andi: Yogyakarta.

Tjiptono, Fandy (2014). Strategi pemasaran. Edisi 4. ANDI: Yogyakarta Tjiptono, Fandy. (2008). Strategi pemasaran. Edisi 3. ANDI: Yogyakarta

Turuis, T. F. (2019). Analisis Faktor-Faktor Yang Mempengaruhi Loyalitas Nasabah Tabungan Bunaken Pada PT. Bank SulutGo Kantor Cabang Pembantu Ranotana. JURNAL RISET BISNIS DAN MANAJEMEN, 7(4).

Wantara, P., \& Tambrin, M. (2019). The Effect of Price and Product Quality Towards Customer Satisfaction and Customer Loyalty on Madura Batik. International Tourism and Hospitality Journal, 2(1), 1-9.

Xie, Y. (2020). The relationship among marketing mix, customer satisfaction and customer loyalty of Chinese tourists to budget hotel of central Bangkok.

Yunita, D., Ali, H. (2017). Model of Purchasing Decision (Renting) of Generator Set: Analysis of Product Quality, Price an Service at PT. Hartekprima Listrindo. Scholars Journal of Economics, Business and Management, e-ISSN, 2348-5302. 